\title{
Compositional difference in antioxidant and antibacterial activity of all parts of the Carica papaya using different solvents
}

\author{
Nazia Asghar ${ }^{1}$, Syed Ali Raza Naqvi, Zaib Hussain², Nasir Rasool', Zulfiqar Ali Khan', Sohail Anjum Shahzad³, \\ Tauqir A. Sherazi ${ }^{3}$, Muhammad Ramzan Saeed Ashraf Janjua ${ }^{4}$, Saeed Ahmad Nagra ${ }^{2 \wedge}$, Muhammad Zia-Ul-Haq ${ }^{5}$ \\ and Hawa Ze Jaafar ${ }^{6 *}$
}

\begin{abstract}
Background: Carica papaya is a well known medicinal plant used in the West and Asian countries to cope several diseases. Patients were advised to eat papaya fruit frequently during dengue fever epidemic in Pakistan by physicians. This study was conducted to establish Polyphenols, flavonoids and antioxidant potential profile of extracts of all major parts of the C. papaya with seven major solvents i.e. water, ethanol, methanol, n-butanol, dichloromethane, ethyl acetate, and n-hexane.

Results: TPC, TFC, antioxidant and antibacterial potential were determined using different aqueous and organic solvents in addition to the determination of trace element in leaves, pulp and peel of C. papaya. Total soluble phenolics and flavonoids were found in promising quantity ( $\approx 66 \mathrm{mg} \mathrm{GAE} / \mathrm{g}$ ) especially in case of methanol and ethanol extracts. Antioxidant activity using DPPH free radical scavenging assay indicated leaves, bark, roots and pulp extracts showed $>75.0 \%$ scavenging potential while leaves and pulp showed 84.9 and $80.9 \%$ inhibition of peroxidation, respectively. Reducing power assay showed leaves, pulp and roots extracts active to reduce $\mathrm{Fe}^{3+}$ to $\mathrm{Fe}^{2+}$ ions. The antibacterial study showed pulp extract is the best to cope infectious action of bacteria.
\end{abstract}

Conclusion: This study was conducted to test the medicinal profile of all parts of C. papaya by extracting secondary metabolites with organic and aqueous solvents. Ethanol and methanol both were found to be the best solvents of choice to extract natural products to get maximum medicinal benefits and could be used to medicinal formulation against different infectious diseases.

\section{Background}

It is no doubt a common person knows the nutritional values of the vegetables and fruits in sense of maintaining the health and preventing the diseases because of vitamins and some special compounds. Yes; they are true in their claim because they don't know about what these compounds perform in their body to make them healthy. Most of the compounds present in fruits and vegetables

\footnotetext{
*Correspondence: drarnaqvi@gmail.com; hawazej@gmail.com

${ }^{\wedge}$ Deceased

${ }^{1}$ Department of Chemistry, Government College University,

Faisalabad 38000, Pakistan

${ }^{6}$ Department of Crop Science, Faculty of Agriculture, UPM,

43400 Serdang, Selangor, Malaysia

Full list of author information is available at the end of the article
}

may modify a multitude of mechanisms that are known in proliferation of diseases. The rest of the nutrients may take part in body building. However, it is widely accepted that these are the fruits and vegetables that have potential to reduce the risk of oxidative stress related diseases [1]. Recent studies have investigated the role of dietary factors in reducing the risk of chronic disease. The results of these investigations concluded if a person who set the fruits and vegetables a necessary part of his diet could reduce $>50 \%$ the risk of oxidative stress diseases and cancer particularly gastrointestinal tract cancer. Understanding of the relationship between food nutrients and health is very necessary as there are about 25,000 biologically active compounds which have ability to cope with

\section{量 Springer}

(C) 2016 Asghar et al. This article is distributed under the terms of the Creative Commons Attribution 4.0 International License (http://creativecommons.org/licenses/by/4.0/), which permits unrestricted use, distribution, and reproduction in any medium, provided you give appropriate credit to the original author(s) and the source, provide a link to the Creative Commons license, and indicate if changes were made. The Creative Commons Public Domain Dedication waiver (http://creativecommons.org/ publicdomain/zero/1.0/) applies to the data made available in this article, unless otherwise stated. 
oxidants working in human body directly or indirectly [2-4].

Oxidants mainly the free radical moieties such as nitric monoxide (NO), superoxide $\left(\mathrm{O}_{2}^{-)}\right.$and hydroxyl $\left(\mathrm{OH}^{-}\right)$ and molecules like hydrogen peroxide $\left(\mathrm{H}_{2} \mathrm{O}_{2}\right)$ and peroxynitrite $\left(\mathrm{ONOO}^{-}\right)$are produced as a result of numerous physiological and biochemical processes. Although these species perform key biological functions in body such as oxygen carrier radicals involve in regulation of soluble guanylatecyclase activity, signal transduction and gene transcription; nitrogen carrier species involve in leukocytes adhesion, hemodynamics, thrombosis, platelets aggregation, signaling molecule that essentially regulate the relaxation and proliferation of vascular smooth muscle cells, angiogenesis and vascular tone [5]. In addition to these activities, these moieties also involve in oxidative damage to lipid, proteins and DNA in living bodies that cause many chronic diseases e.g. cancer, cardiovascular, diabetics etc. ROS play crucial role in growing the chronic disorders because it attacks especially free radical sensitive cells such as post-mitotic glial cells and neurons which lead to cardiovascular, neurodegenerative diseases and cancer [6].

All these species which have serious deleterious effect in human body no longer free in the presence of antioxidants to perform its damaging action in body. Antioxidants are those species which deplete or at least debilitate the function of the oxidants. At first our body itself produces some compounds known as endogenous compounds in response to the free radicals or oxidants generation to fix its action. However, overproduction of the free radicals or ROS or oxidants in body suppresses or even deactivates the endogenous antioxidant defensive system. Over production of free radicals might be due to the extensive electromagnetic radiation exposure, eating non-food grade dietary items, and extensive muscular work. Unchecked over production of free radicals may cause highly chronic diseases such as aging, Parkinson's disease, Alzheimer's disease and many other neural disorders. These disorders could be slow down or even cured using exogenous compounds (natural or synthetic) [7-9]. Natural antioxidants are enzymatic or nonenzymatic moieties. Polyphenols, carotenoids are famous non-enzymatic antioxidants which are mainly present in nuts, vegetables and fruits. Regular intake of vegetables and fruits dramatically reduce the oxidative stress and its allied risks. Antioxidant components of the fruits and vegetables are responsible for scavenging of free radicals, RNS, ROS, and inhibiting the process trigger the ROS generation [10].

Carica papaya fruit which belongs to the family Caricaceae grown in different areas of the world, is one of them which are well recognized as a potential medicinal fruit possessing unique food values and biological potentials [11]. Medicinal uses of different parts of C. papaya has been reported such as leaves smoke were used for asthma relief and poultice for nervous pains, pulp for preventing rheumatism and urine acidity, and flowers for jaundice and hypertension [12, 13]; however medicinal uses of C. papaya vary from area to area. In Pakistan it is suggested by physicians to dengue fever patients to eat papaya in good quantity due to its immune booster, antiviral and antioxidant properties. In this study we determined the antioxidant and antibacterial potential profile of all major parts extracts of the C. papaya in seven common organic and aqueous solvents.

\section{Results and discussion Extraction yield}

The results showed that the extraction yields obtained was affected by the solvent used as shown in Table 1 . Difference in yields of extracts affected with polarity of solvents and various compounds present in different parts of the C. papaya. The highest yield was obtained by the aqueous solvent; 29/100 g dry powder of roots and 28/100 g dry powder of leaves. The poorest yield was achieved with n-hexane $(0.4 / 100 \mathrm{~g}$ dry powder of pulp). The extraction yield was obtained in the following descending order; water $>$ methanol $>$ ethanol $>$ ethyl acetate $>$ dichloromethane $>n$-butanol $>n$-hexane. Polarity of the solvent, nature of the extracted compounds and extraction process highly affects antioxidant and antibacterial activities of the plant extracts [14].

\section{Metal profile}

Metals are present in earth's crust and its contents distribute in the nature through food cycle and energy cycle. Trace metals are necessary entities of biological systems to trigger and regulate the key body functions. Fruits and vegetables are main sources of trace elements such as iron $(\mathrm{Fe})$, zink $(\mathrm{Zn})$, cobalt $(\mathrm{Co})$ and copper $(\mathrm{Cu})$ which combines with certain biomolecules to produce enzymes and co-enzymes to catalyze and trigger certain body functions $[15,16]$. Trace elements also assist the endogenous antioxidant activities. Without processing pulp is the most common edible part of fruits to fulfill the nutritional requirement of trace elements. The results showed C. papaya pulp contain trace amount of $\mathrm{Fe}$, and $\mathrm{Zn}$ (2.56 and 0.06 respectively) and very poor quantity of $\mathrm{Cu}$. However, a good quantity was detected in leaves and peels as shown in Table 2. The routine use of peel and leaves is not possible as pulp but the extracts of leaves and peels could be used as mineral source after necessary processing in addition to antioxidants source. 
Table 1 Extraction yield ( $\mathrm{g} / 100 \mathrm{~g}$ dry matter) of different parts of $C$. papaya in seven different solvents (mean; $n=3$ )

\begin{tabular}{|c|c|c|c|c|c|c|}
\hline $\begin{array}{l}\text { Extracting } \\
\text { Solvents }\end{array}$ & Roots & Bark & Peels & Pulp & Seeds & Leaves \\
\hline n-Hexane & 03.95 & 05.99 & 04.66 & 00.40 & 00.71 & 08.56 \\
\hline Dichloromethane & 07.10 & 24.22 & 09.83 & 08.74 & 06.27 & 13.85 \\
\hline n-Butanol & 10.10 & 09.09 & 04.15 & 02.70 & 01.32 & 08.25 \\
\hline Ethyl acetate & 17.00 & 10.93 & 12.27 & 11.48 & 10.12 & 18.89 \\
\hline Water & 29.00 & 21.92 & 22.00 & 14.57 & 12.84 & 28.00 \\
\hline Methanol & 19.46 & 10.90 & 16.50 & 13.32 & 14.32 & 15.90 \\
\hline Ethanol & 20.89 & 14.47 & 15.66 & 10.31 & 12.36 & 11.47 \\
\hline
\end{tabular}

Table 2 Metal profile of C. papaya leaves, pulp and peel

\begin{tabular}{lllllr}
\hline Sample & Iron $(\mathrm{Fe})$ & Lead $(\mathbf{P b})$ & Cobalt $(\mathbf{C o})$ & Copper $(\mathbf{C u})$ & Zinc $(\mathbf{Z n})$ \\
\hline Leaves & $13.55 \pm 0.01$ & $5.00 \pm 0.01$ & $0.01 \pm 0.00$ & $7.75 \pm 0.02$ & $20.01 \pm 0.00$ \\
Pulp & $2.56 \pm 0.01$ & ND & ND & $0.00 \pm 0.00$ & $0.06 \pm 0.00$ \\
Peels & $0.88 \pm 0.40$ & $3.00 \pm 0.1$ & $0.02 \pm 0.03$ & $4.01 \pm 0.90$ & $10.03 \pm 0.00$ \\
\hline
\end{tabular}

Mean \pm S.E (ng/100 g dry extract)

ND not detected

\section{Determination of total phenolic contents}

Nutritional values of food mainly based on TPC and TFC profile. Both contents are considered the index of medicinal values of natural products [17]. TPC was determined by standard method using Folin-Ciocalteu reagent and the results were expressed in term of $\mathrm{mg}$ GAE/g dry matter (Table 3). The organic solvent extracts of different parts of C. papaya had prominent yield. TPC determined in different parts of the $C$. papaya ranging from 1.22-65.12 mg GAE/g dry powder. The most extractable solvents of phenolics were the ethanol and methanol. The highest phenolic compounds was achieved with ethanol (65.12 mg GAE/g dry leave powder and $61.25 \mathrm{mg}$ GAE/g dry bark powder) followed by methanol solvent (54.28 mg GAE/g dry leave powder). Whereas poorest phenolics were obtained with dichloromethan solvent (1.2 mg GAE/g dry root powder). Vuong et al. (2013) reported TPC of C. papaya fruit extracts with methanol and ethanol solvent 15.03 and $9.43 \mathrm{mg} \mathrm{GAE} / \mathrm{g}$ dry powder, respectively. These contents were lower than we determined, however leave extract with ethanol solvent showed $63.59 \mathrm{mg}$ GAE/g crude powder which is in good agreement with our results $(65.12 \mathrm{mg} \mathrm{GAE} / \mathrm{g}$ dry powder of leave) [17]. Other organic solvents such as n-hexane, n-butanol, and ethyl acetate showed mild extraction yield. The poor extraction could be explained on the bases that these solvents contain dominant non-polar nature character while methanol and ethanol both contain moderate polar to non-polar behavior which is more favorable to extract phenolics and flavonoids. Comparatively less

Table 3 Total phenolic contents (mg GAE/g) values of all major part extracts in aqueous and organic solvents of $C$. papaya (mean $\pm \mathrm{SE} ; n=3$ )

\begin{tabular}{llllllll}
\hline Extracting Solvents & Leaves & Bark & roots & Peels & seeds & pulp & LSD 5\% \\
\hline n-Hexane $^{* * *}$ & $10.60 \pm 0.06^{\mathrm{b}}$ & $09.85 \pm 0.03^{\mathrm{c}}$ & $02.64 \pm 0.00^{\mathrm{f}}$ & $07.32 \pm 0.05^{\mathrm{d}}$ & $06.74 \pm 0.02^{\mathrm{e}}$ & $15.92 \pm 0.03^{\mathrm{a}}$ & 0.07 \\
Dichloromethane $^{* * * *}$ & $11.77 \pm 0.03^{\mathrm{e}}$ & $21.60 \pm 0.04^{\mathrm{a}}$ & $01.22 \pm 0.01^{f}$ & $21.15 \pm 0.12^{\mathrm{b}}$ & $16.02 \pm 0.03^{\mathrm{d}}$ & $19.62 \pm 0.04^{\mathrm{c}}$ & 0.10 \\
n-Butanol $^{* * *}$ & $21.69 \pm 0.03^{\mathrm{c}}$ & $25.80 \pm 0.04^{\mathrm{a}}$ & $05.83 \pm 0.02^{\mathrm{e}}$ & $24.80 \pm 0.04^{\mathrm{b}}$ & $25.85 \pm 0.09^{\mathrm{a}}$ & $20.93 \pm 0.04^{\mathrm{d}}$ & 0.09 \\
Ethyl acetate $^{* * *}$ & $27.80 \pm 0.02^{\mathrm{d}}$ & $28.80 \pm 0.05^{\mathrm{c}}$ & $09.39 \pm 0.05^{\mathrm{f}}$ & $27.21 \pm 0.14^{\mathrm{e}}$ & $32.52 \pm 0.49^{\mathrm{a}}$ & $31.88 \pm 0.01^{\mathrm{b}}$ & 0.37 \\
Water $^{* * *}$ & $49.94 \pm 0.60^{\mathrm{a}}$ & $31.31 \pm 0.05^{\mathrm{d}}$ & $19.92 \pm 0.04^{\mathrm{f}}$ & $32.23 \pm 0.64^{\mathrm{c}}$ & $27.94 \pm 0.09^{\mathrm{c}}$ & $37.78 \pm 0.11^{\mathrm{b}}$ & 0.65 \\
Methanol $^{* * *}$ & $54.28 \pm 0.10^{\mathrm{a}}$ & $37.09 \pm 0.52^{\mathrm{d}}$ & $41.72 \pm 0.54^{\mathrm{b}}$ & $35.15 \pm 0.53^{\mathrm{e}}$ & $38.86 \pm 0.82^{\mathrm{c}}$ & $38.15 \pm 0.53^{\mathrm{c}}$ & 0.89 \\
Ethano $^{* * *}$ & $65.12 \pm 1.21^{\mathrm{a}}$ & $61.25 \pm 0.10^{\mathrm{b}}$ & $49.08 \pm 0.09^{\mathrm{c}}$ & $43.79 \pm 1.20^{\mathrm{e}}$ & $43.42 \pm 0.06^{\mathrm{f}}$ & $48.49 \pm 0.18^{\mathrm{d}}$ & 0.27 \\
\hline
\end{tabular}

Values with same letter in superscript in row do not differ significantly

NS non-significant

*** Significant at 0.001 level 
extraction of phenolics with water solvent is due to the extraction with high percentage of impurities [18].

All phenolic contents do not have equal antioxidant strength; it is investigated highly polar phenolic contents extracted with water showed week antioxidant potential while mild polar phenolic contents commonly extracted with high yield with ethanol and methanol solvents showed awesome antioxidant potential which have great credibility in contrast to the synthetic antioxidants [19]. Synthetic antioxidants in addition to quench oxidation process were also found to involve in toxicity such as genotoxicity and carcinogenicity which is the key reason of reviving the attention toward natural products in recent years [20]. This study also has showed good extraction with ethanol solvent and also promising antioxidant and antibacterial potential as compared to other tested solvents. Statistical analysis showed strong significant difference in total phenolics among different parts $(\mathrm{P} \leq 0.001)$ Fig. 1.

\section{Determination of total flavonoid contents}

Flavonoids are the second important figure of natural extracts to evaluate the medicinal importance of plants. It is sub class of polyphenols having benzo- $\gamma$-pyrone structure. In literature more than 6000 flavonoid compounds have been cited that was identified in plants. Many of which are present in fruits and vegetables. These compounds are responsible to protect plants from microbial and insects attack while in human body play defensive role as anti-inflammatory, anti-microbial, anticancer and anti-oxidant moieties [21-24]. Flavonoids extraction was found to be depend on the solvent used as shown in Table 4. Statistical analysis showed strong significant difference among flavonoid contents of different parts $(\mathrm{P} \leq 0.001)$. The highest flavonoid contents were extracted with ethanol solvent $(21.88 \mathrm{mg} \mathrm{CE} / \mathrm{g}$ dry powder) followed by methanol. The lowest contents $(0.13 \mathrm{mg}$ $\mathrm{CE} / \mathrm{g}$ dry powder) were found in dichloromethane extract followed by $n$-hexane and n-butanol extracts. Harnly and co-workers (2006) calculated and determined the flavonoid compounds (flavan-3-ols, anthocyanins, flavanones, flavones, and flavonols) in US based 31 fruitrs and found the most prominent medicinally important fruits such as blackberries and blueberries contain promising quantity of flavonoids, 202.5 and $79.9 \mathrm{mg} \mathrm{CE} / 100 \mathrm{~g}$ fresh samples respectively [25]. Both blackberries and blueberries are best known for its antimicrobial and anti-oxidant activities and are being marketed in the form of processed extracts to improve mental function, reduce the risk of cancer, as anti-aging agent, and overall improvement in health. Different parts of C. papaya also showed promising quantity of these valued compounds which could be further processed as a ready to use source of flavonoids.

\section{Antioxidant activities}

\section{Determination of DPPH free radical scavenging potential}

Polyphenols are considered the index of antioxidant potential of fruits and vegetables. Different assays are being conducted to quantify the antioxidant strength. DPPH free radical scavenging assay is considered one of the best authentic assay for antioxidant study [26]. DPPH is an organic stable free radical which gives purple color in solution with maximum absorption at $517 \mathrm{~nm}\left(\lambda_{\max }\right)$ $[27,28]$. On accepting an electron or free radical specie its color shifts from purple to yellow and also decrease in absorbance at $\lambda_{\max }$. This change in absorption makes the bases of anti-oxidant quantification. The DPPH free radical scavenging assay results showed significant difference in scavenging act ivity among different parts $(\mathrm{P} \leq 0.01$ and $\mathrm{P} \leq 0.001)$ as shown in Fig. 2 . It shows that
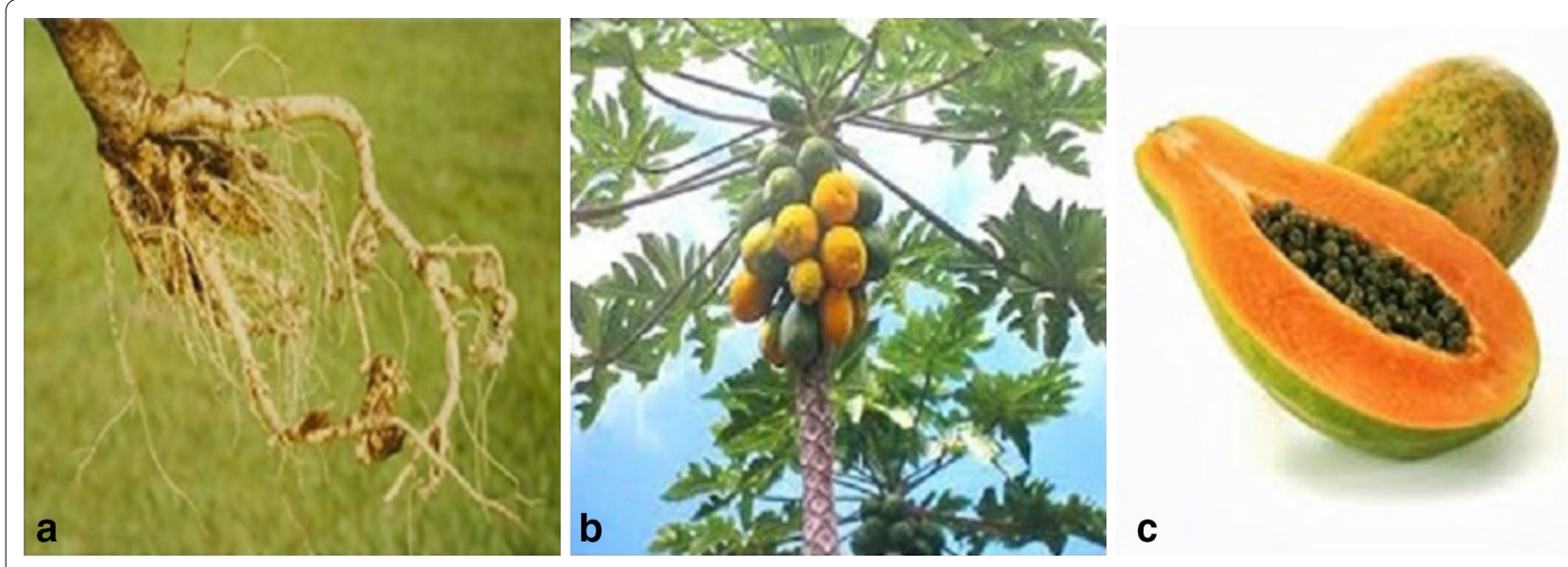

Fig. 1 Major parts of C. papaya a roots $\mathbf{b}$ leaves, bark and fruit and c fruit pulp and seeds 
Table 4 TFC values ( $\mathrm{mg} \mathrm{CE} / \mathrm{g}$ dry powder) of all major part extracts in aqueous and organic solvent of $\mathrm{C}$. papaya $($ mean $\pm S E ; n=3)$

\begin{tabular}{|c|c|c|c|c|c|c|c|}
\hline Extracting solvents & Leaves & Bark & Roots & Peels & Seeds & Pulp & LSD $5 \%$ \\
\hline n-Hexane & $05.70 \pm 0.01^{\mathrm{a}}$ & $00.60 \pm 0.00^{e}$ & $00.59 \pm 0.06^{e}$ & $01.10 \pm 0.01^{c}$ & $00.90 \pm 0.13^{d}$ & $04.90 \pm 0.01^{b}$ & 0.10 \\
\hline Dichloromethane $e^{* * *}$ & $06.64 \pm 0.07^{b}$ & $01.58 \pm 0.01^{d}$ & $00.13 \pm 0.01^{f}$ & $01.23 \pm 0.12^{\mathrm{e}}$ & $01.65 \pm 0.01^{c}$ & $08.74 \pm 0.02^{\mathrm{a}}$ & 0.10 \\
\hline n-Butanol ${ }^{* * *}$ & $08.39 \pm 0.02^{b}$ & $02.61 \pm 0.02^{e}$ & $03.62 \pm 0.25^{d}$ & $03.72 \pm 0.01^{d}$ & $04.66 \pm 0.04^{c}$ & $10.87 \pm 0.02^{\mathrm{a}}$ & 0.19 \\
\hline Ethyl acetate $^{\text {ns }}$ & $11.20 \pm 0.07^{\mathrm{a}}$ & $08.59 \pm 0.03^{a}$ & $10.21 \pm 0.03^{a}$ & $08.57 \pm 0.01^{a}$ & $10.21 \pm 0.01^{a}$ & $11.23 \pm 0.01^{a}$ & 423.41 \\
\hline Water $^{* * *}$ & $12.61 \pm 0.50^{\mathrm{a}}$ & $10.11 \pm 0.53^{c}$ & $12.37 \pm 0.03^{a}$ & $12.93 \pm 0.29^{a}$ & $06.56 \pm 0.14^{d}$ & $12.06 \pm 0.20^{a b}$ & 0.59 \\
\hline Methanol $^{* * *}$ & $15.54 \pm 0.12^{b}$ & $15.84 \pm 0.25^{b}$ & $16.69 \pm 0.22^{\mathrm{a}}$ & $13.92 \pm 0.13^{c}$ & $08.62 \pm 0.16^{d}$ & $08.24 \pm 0.08^{e}$ & 0.30 \\
\hline Ethanol $^{* * *}$ & $21.88 \pm 0.06^{a}$ & $18.20 \pm 0.53^{d}$ & $18.99 \pm 0.02^{c}$ & $19.81 \pm 0.02^{b}$ & $10.44 \pm 0.17^{f}$ & $16.26 \pm 0.20^{e}$ & 0.41 \\
\hline
\end{tabular}

Values with same letter in superscript in row do not differ significantly

NS non-significant

*** Significant at 0.001 level

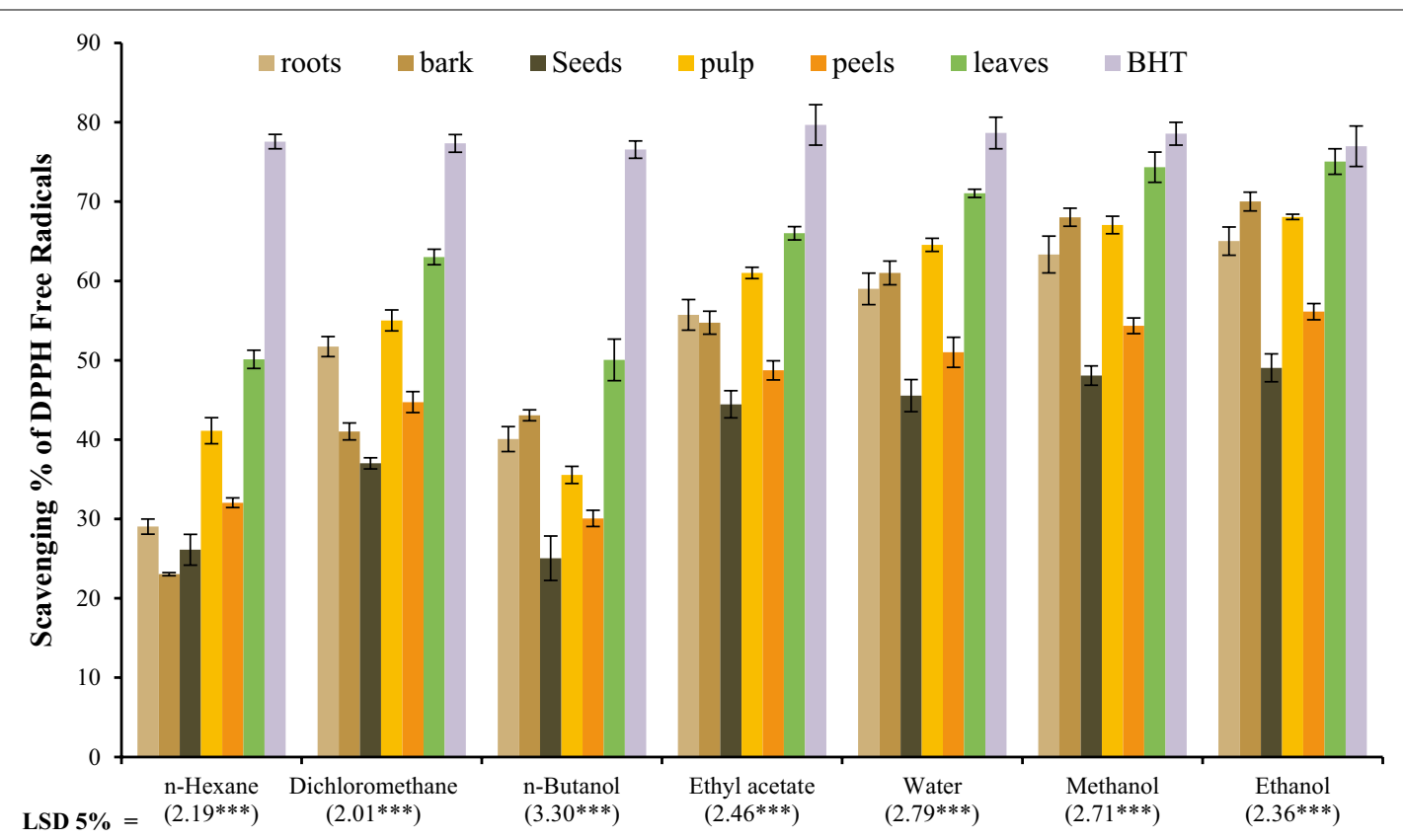

Fig. 2 DPPH free radical scavenging activity study of all major part extracts in aqueous and organic solvents of C. papaya (mean $\pm S E ; n=3$; *** = significant at 0.001 level)

the highest DPPH free radical scavenging potential was found with ethanol solvent extracts of leaves $(75.05 \%)$ followed by pulp extract with same solvent (68.07\%). Carica papaya bark and roots also showed promising DPPH radical scavenging potential; particularly in case of ethanol and methanol extracts in which bark extracts superseded the scavenging potential of pulp. The highest DPPH free radical scavenging potential of bark might be due to the promising quantity of phenolic and flavonoid contents in their extracts. The lowest DPPH free radical scavenging potential appeared in the case of n-hexane and n-butanol extracts (Fig. 2) that might be due to difference in polarity of extracted solvents and compounds.

\section{$\%$ Inhibition of linoleic acid peroxidation}

Lipid peroxidation (oxidation of lipid) by ROS imposes deteriorated effect on human body and is a crucial step in the pathogenesis of several diseases. Generally ROS readily after its formation attacks the polyunsaturated fatty acids chain of cell membrane and start self-propagated chain reaction which ends in the damaging of cell and tissues and consequently the initiation of the disease. Fruits and vegetables with good potential to inhibit lipid 
peroxidation are considered most important. Percent inhibition of linoleic acid peroxidation by aqueous and organic solvents extracts of different parts of $C$. papaya showed strong significant difference $(\mathrm{P} \leq 0.001)$ as shown in Fig. 3. The highest linoleic acid peroxidation inhibition was determined with ethanol solvent extract of leave which was $85 \%$ followed by methanol extract ( $82 \%$ ) and ethanol extract of pulp (81\%). The lowest inhibition value was determined with $\mathrm{n}$-hexane solvent extract of seeds $(8 \%)$. Other solvents ( $\mathrm{n}$-hexane, $\mathrm{n}$-butanol, and dichloromethane) due to their mild polarity remained unable to extract antioxidants and consequently showed weak inhibition of linoleic acid peroxidation. Ethanolic extract superseded the BHT (control) potential to inhibit the linoleic acid peroxidation.

\section{Determination of reducing power}

Figure 4 shows the reducing power of different parts of C. papaya as a function of concentration. The assay bases on the gradual color change by reduction of the oxidants as function of reducing agent concentration. In this assay, the yellow color of the test solution appears due to the $\mathrm{Fe}^{3+} /$ ferricyanide complex which gradually changes to different shades of green and blue colors on gradual reduction of $\mathrm{Fe}^{3+}-\mathrm{Fe}^{2+}$ as concentration of antioxidant increases. The reduced $\mathrm{Fe}^{3+}-\mathrm{Fe}^{2+}$ concentration is determined by measuring the absorption of Perl's Prussian blue at $700 \mathrm{~nm}$ [29]. The absorption is directly related to reducing power and consequently antioxidant potential. The highest reducing power was found with ethanol solvent extract (absorbance 1.99) followed by water (absorption 1.87) and methanol (absorption 1.57). The least absorbance was observed with n-hexane solvent extract of roots (absorbance 0.48). Other extracts such as n-butanol, dichloromethane and ethyl acetate extracts showed absorbance in the range of 0.6-1.2. While in contrast to all extracts, BHT which is taken as control showed absorbance 1.99 at $100 \mu \mathrm{g} / \mathrm{mL}$ concentration which is comparable to ethanol extract of root (absorbance 1.99) and pulp (absorbance 1.98).

\section{Antibacterial activity}

Antibacterial activities of different part extracts of $C$. papaya against multidrug resistance bacterial strains were listed in Table 5. Statistical analysis showed nonsignificant to significant difference $(\mathrm{P} \leq 0.05, \mathrm{P} \leq 0.01$ or $\mathrm{P} \leq 0.001$ ). Organic and aqueous solvent extracts were tested against four bacterial strains i.e. Staphylococcus aureus, and Bacillus cereus(Gram-positive), Escherichia coli and Pasteurellamultocida(Gram-negative). The antibacterial activity result showed the ethanolic extract of pulp was more active against bacterial strains (zone of inhibition 16-18 $\mathrm{mm}$ ) as compared to other solvent extracts. Ethanolic extract of leaves also showed the zoon of inhibition in the range of $14-16 \mathrm{~mm}$ against all four bacterial strains, while the minimum zone of inhibition

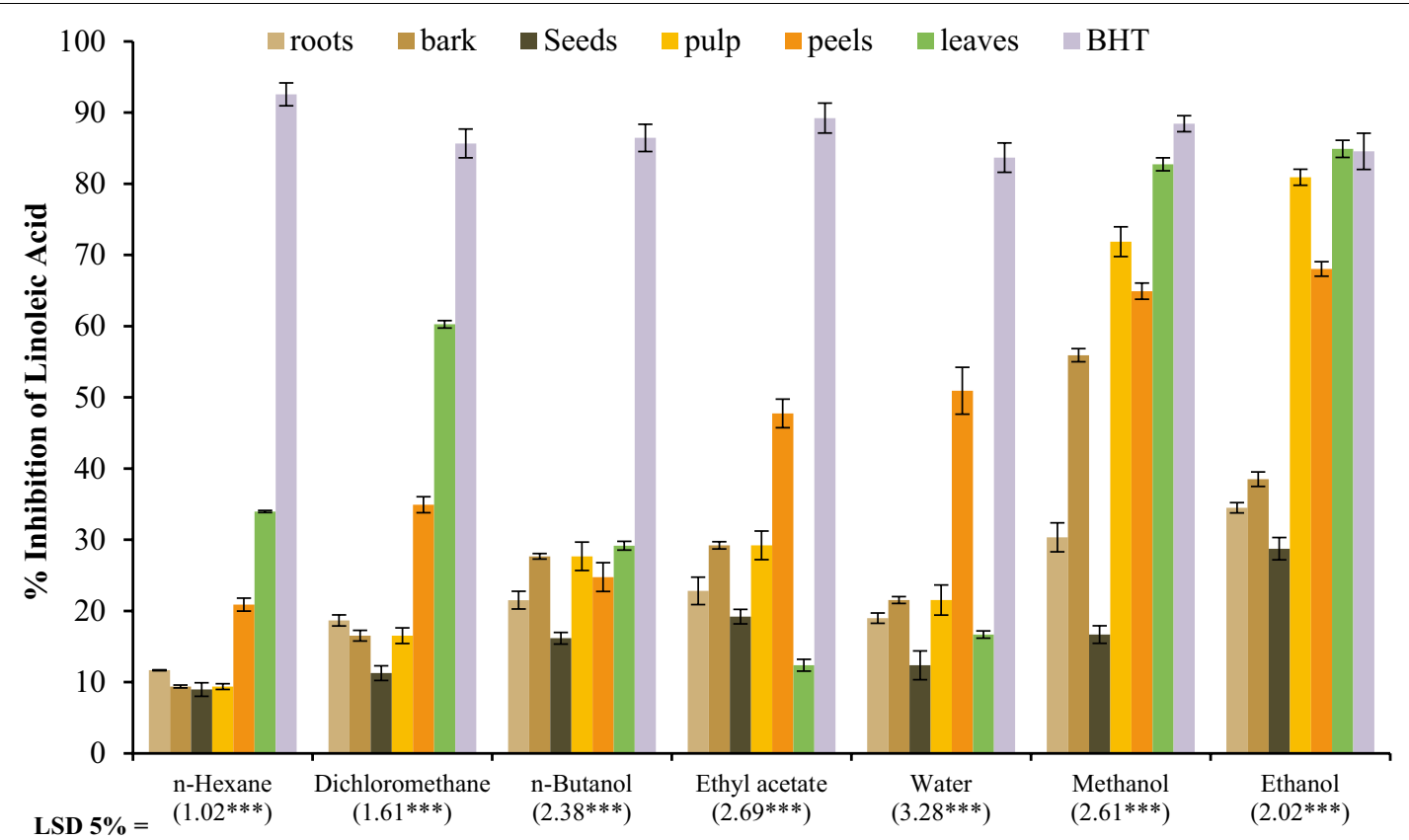

Fig. 3 Percent inhibition of linoleic acid peroxidation study of all major part extracts in aqueous and organic solvents of C. papaya (mean $\pm \mathrm{SE}$; $n=3 ;{ }^{* * *}=$ significant at 0.001 level) 


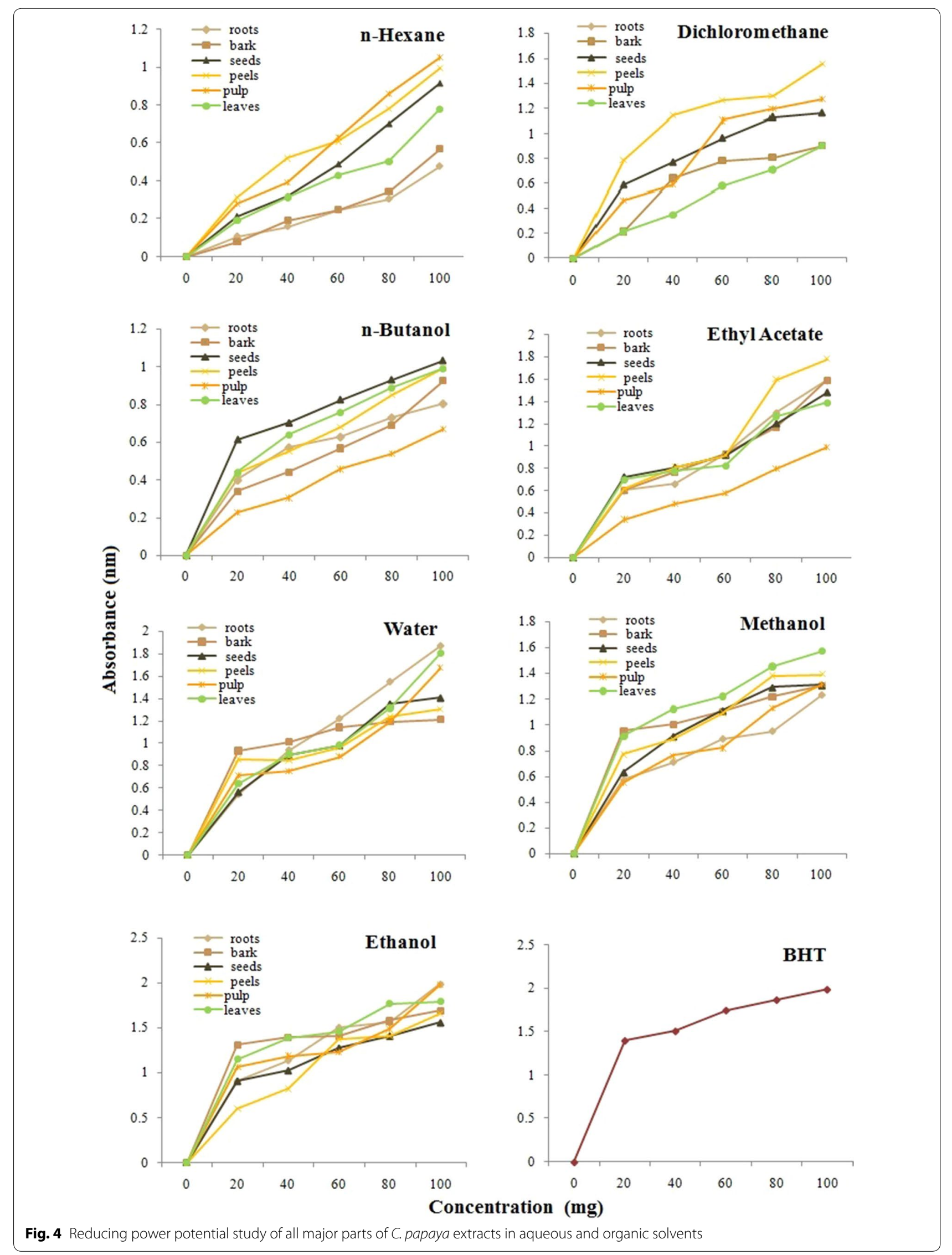


Table 5 Antibacterial activity of all major part extracts in aqueous and organic solvent of C. papaya against gram positive and gram negative bacterial strains (mean $\pm \mathrm{SE} ; n=3$ )

\begin{tabular}{|c|c|c|c|c|c|c|c|c|}
\hline Organisms & n-hexane & Dichloro-methan & n-butanol & Ethyl-acetate & Water & Methanol & Ethanol & Cipro-floxacin \\
\hline \multicolumn{9}{|l|}{ Pulp } \\
\hline S.aureus & $7.8 \pm 0.2^{b}$ & $10.5 \pm 0.5^{a b}$ & $9.0 \pm 0.5^{b}$ & $11.9 \pm 1.3^{\mathrm{a}}$ & $9.0 \pm 0.5^{a}$ & $13.0 \pm 0.0^{b}$ & $17.8 \pm 0.0^{a}$ & $21.5 \pm 0.8$ \\
\hline B. cereus & $6.8 \pm 0.5^{c}$ & $10.1 \pm 0.5^{a b}$ & $10.0 \pm 0.2^{a}$ & $12.2 \pm 0.6^{a}$ & $8.7 \pm 0.8^{a}$ & $12.9 \pm 0.8^{b}$ & $15.9 \pm 0.8^{a}$ & $18.6 \pm 0.6$ \\
\hline E. coli & $9.3 \pm 0.1^{a}$ & $11.2 \pm 0.1^{\mathrm{a}}$ & $9.0 \pm 0.1^{b}$ & $10.1 \pm 0.0^{a}$ & $9.2 \pm 0.0^{\mathrm{a}}$ & $11.5 \pm 0.1^{b}$ & $16.9 \pm 0.0^{a}$ & $22.3 \pm 1.1$ \\
\hline P. multocida & $7.9 \pm 0.3^{b}$ & $9.7 \pm 0.7^{b}$ & $10.0 \pm 0.9^{a}$ & $11.5 \pm 1.2^{\mathrm{a}}$ & $7.9 \pm 2.4^{\mathrm{a}}$ & $14.8 \pm 1.7^{\mathrm{a}}$ & $18.1 \pm 1.2^{\mathrm{a}}$ & $21.2 \pm 1.2$ \\
\hline LSD $5 \%$ & $0.59^{* * *}$ & $0.94^{*}$ & $1.01^{*}$ & $1.76^{\mathrm{ns}}$ & $2.41^{\mathrm{ns}}$ & $1.80^{*}$ & $1.40^{*}$ & \\
\hline \multicolumn{9}{|l|}{ Leaves } \\
\hline S.aureus & $6.7 \pm 0.2^{a}$ & $6.7 \pm 0.2^{b}$ & $5.9 \pm 0.4^{c}$ & $9.2 \pm 0.3^{a}$ & $7.3 \pm 0.1^{c}$ & $9.2 \pm 0.2^{d}$ & $16.2 \pm 0.3^{a}$ & $21.5 \pm 0.8$ \\
\hline B. cereus & $5.7 \pm 0.2^{b}$ & $5.2 \pm 0.4^{d}$ & $5.9 \pm 0.4^{c}$ & $7.2 \pm 0.3^{c}$ & $9.0 \pm 0.2^{b}$ & $11.0 \pm 0.1^{b}$ & $14.5 \pm 0.2^{c}$ & $18.6 \pm 0.6$ \\
\hline E. coli & $6.9 \pm 0.0^{a}$ & $6.3 \pm 0.0^{c}$ & $7.5 \pm 0.1^{b}$ & $8.2 \pm 0.2^{b}$ & $9.0 \pm 0.1^{b}$ & $10.0 \pm 0.4^{c}$ & $14.3 \pm 0.1^{c}$ & $22.3 \pm 1.1$ \\
\hline P. multocida & $5.6 \pm 0.9^{b}$ & $7.2 \pm 0.2^{\mathrm{a}}$ & $8.1 \pm 0.1^{\mathrm{a}}$ & $9.2 \pm 0.2^{a}$ & $9.2 \pm 0.1^{\mathrm{a}}$ & $13.2 \pm 0.5^{a}$ & $15.3 \pm 0.3^{a}$ & $21.2 \pm 1.2$ \\
\hline LSD $5 \%$ & $0.97^{*}$ & $0.31^{* * *}$ & $0.60^{* * *}$ & $0.45^{* * *}$ & $0.25^{* * *}$ & $0.62^{* * *}$ & $0.40^{* * *}$ & \\
\hline \multicolumn{9}{|l|}{ Seed } \\
\hline S.aureus & $5.5 \pm 0.2^{b}$ & $4.6 \pm 0.0^{c}$ & $9.0 \pm 0.2^{b}$ & $9.7 \pm 0.4^{b}$ & $8.7 \pm 0.3^{c}$ & $9.9 \pm 0.4^{b}$ & $14.0 \pm 0.3^{a}$ & $21.5 \pm 0.8$ \\
\hline B. cereus & $6.1 \pm 0.3^{a}$ & $7.3 \pm 0.4^{a}$ & $9.5 \pm 0.1^{\mathrm{a}}$ & $9.1 \pm 0.1^{c}$ & $10.1 \pm 0.0^{a}$ & $11.3 \pm 0.0^{\mathrm{a}}$ & $11.7 \pm 0.2^{b}$ & $18.6 \pm 0.6$ \\
\hline E. coli & $5.0 \pm 0.1^{c}$ & $6.8 \pm 0.0^{b}$ & $8.7 \pm 0.2^{c}$ & $10.5 \pm 0.0^{a}$ & $9.6 \pm 0.1^{b}$ & $10.9 \pm 0.3^{\mathrm{a}}$ & $14.0 \pm 0.1^{\mathrm{a}}$ & $22.3 \pm 1.1$ \\
\hline P. multocida & $6.3 \pm 0.2^{a}$ & $6.5 \pm 0.3^{b}$ & $8.4 \pm 0.2^{c}$ & $9.0 \pm 0.1^{c}$ & $10.4 \pm 0.3^{a}$ & $10.1 \pm 0.1^{b}$ & $13.8 \pm 0.1^{\mathrm{a}}$ & $21.2 \pm 1.2$ \\
\hline LSD $5 \%$ & $0.36^{* * *}$ & $0.47^{* * *}$ & $0.35^{* * *}$ & $0.38^{* * *}$ & $0.38^{* * *}$ & $0.49^{* * *}$ & $0.31^{* * *}$ & \\
\hline \multicolumn{9}{|l|}{ Roots } \\
\hline S. aureus & $4.0 \pm 0.1^{b}$ & $7.0 \pm 1.0^{\mathrm{a}}$ & $8.0 \pm 0.3^{a}$ & $8.3 \pm 0.3^{b}$ & $7.2 \pm 0.4^{a}$ & $10.2 \pm 0.4^{\mathrm{a}}$ & $10.5 \pm 1.0^{\mathrm{a}}$ & $21.5 \pm 0.8$ \\
\hline B. cereus & $3.8 \pm 0.9^{b}$ & $7.0 \pm 0.9^{a}$ & $7.6 \pm 0.6^{a}$ & $8.2 \pm 0.6^{b}$ & $8.0 \pm 0.4^{a}$ & $9.3 \pm 0.2^{a}$ & $9.5 \pm 0.0^{\mathrm{a}}$ & $18.6 \pm 0.6$ \\
\hline E. coli & $5.8 \pm 0.0^{a}$ & $8.6 \pm 0.1^{a}$ & $9.1 \pm 0.0^{\mathrm{a}}$ & $8.0 \pm 0.4^{b}$ & $8.5 \pm 0.4^{a}$ & $9.9 \pm 0.2^{\mathrm{a}}$ & $11.0 \pm 0.0^{a}$ & $22.3 \pm 1.1$ \\
\hline P. multocida & $5.5 \pm 0.1^{\mathrm{a}}$ & $8.1 \pm 0.1^{\mathrm{a}}$ & $8.7 \pm 1.0^{\mathrm{a}}$ & $9.0 \pm 0.0^{a}$ & $10.0 \pm 1.9^{a}$ & $10.2 \pm 1.2^{\mathrm{a}}$ & $11.7 \pm 1.0^{\mathrm{a}}$ & $21.2 \pm 1.2$ \\
\hline LSD $5 \%$ & $0.86^{* *}$ & $1.24^{*}$ & $1.11^{\mathrm{ns}}$ & $0.61^{*}$ & $1.89^{*}$ & $1.26^{\mathrm{ns}}$ & $1.31^{*}$ & \\
\hline \multicolumn{9}{|l|}{ Peels } \\
\hline S. aureus & $5.4 \pm 0.1^{a}$ & $5.6 \pm 0.0^{b}$ & $6.4 \pm 0.1^{d}$ & $7.0 \pm 0.4^{a}$ & $7.7 \pm 0.4^{a}$ & $8.1 \pm 0.3^{c}$ & $12.5 \pm 0.3^{c}$ & $21.5 \pm 0.8$ \\
\hline B. cereus & $5.3 \pm 1.5^{\mathrm{a}}$ & $5.6 \pm 0.2^{b}$ & $6.7 \pm 0.0^{c}$ & $7.4 \pm 0.1^{a b}$ & $7.9 \pm 0.9^{\mathrm{a}}$ & $8.12 \pm 0.1^{c}$ & $14.8 \pm 0.2^{\mathrm{a}}$ & $18.6 \pm 0.6$ \\
\hline E. coli & $6.5 \pm 0.0^{a}$ & $5.8 \pm 0.1^{a b}$ & $7.3 \pm 0.1^{\mathrm{a}}$ & $8.0 \pm 0.4^{a}$ & $8.6 \pm 0.2^{a}$ & $9.1 \pm 0.0^{\mathrm{a}}$ & $13.6 \pm 0.3^{b}$ & $22.3 \pm 1.1$ \\
\hline P. multocida & $5.9 \pm 1.3^{\mathrm{a}}$ & $6.0 \pm 0.1^{a}$ & $7.0 \pm 0.2^{b}$ & $7.8 \pm 0.3^{\mathrm{a}}$ & $8.0 \pm 0.0^{a}$ & $8.8 \pm 0.1^{b}$ & $12.5 \pm 1.2^{c}$ & $21.2 \pm 1.2$ \\
\hline LSD $5 \%$ & $1.87^{\mathrm{ns}}$ & $0.26^{*}$ & $0.18^{* * *}$ & $0.62^{*}$ & $0.96^{\mathrm{ns}}$ & $0.13^{* * *}$ & $0.83^{*}$ & \\
\hline \multicolumn{9}{|l|}{ Bark } \\
\hline S.aureus & $6.9 \pm 0.0^{a}$ & $7.1 \pm 1.2^{\mathrm{a}}$ & $7.5 \pm 1.2^{\mathrm{a}}$ & $8.0 \pm 1.9^{a}$ & $8.0 \pm 1.1^{\mathrm{a}}$ & $8.9 \pm 1.3^{\mathrm{a}}$ & $10.9 \pm 1.1^{\mathrm{a}}$ & $21.5 \pm 0.8$ \\
\hline B. cereus & $6.1 \pm 0.0^{b}$ & $7.3 \pm 1.0^{\mathrm{a}}$ & $7.4 \pm 1.5^{\mathrm{a}}$ & $8.5 \pm 0.3^{a}$ & $8.0 \pm 0.1^{a}$ & $9.1 \pm 1.5^{\mathrm{a}}$ & $10.5 \pm 1.6^{a}$ & $18.6 \pm 0.6$ \\
\hline E. coli & $5.9 \pm 0.1^{b}$ & $7.8 \pm 0.0^{a}$ & $8.0 \pm 0.1^{\mathrm{a}}$ & $8.9 \pm 0.2^{a}$ & $9.0 \pm 0.0^{a}$ & $10.5 \pm 0.0^{a}$ & $11.0 \pm 0.0^{\mathrm{a}}$ & $22.3 \pm 1.1$ \\
\hline P. multocida & $7.5 \pm 0.7^{a}$ & $7.6 \pm 0.3^{a}$ & $8.0 \pm 1.2^{\mathrm{a}}$ & $9.4 \pm 1.4^{\mathrm{a}}$ & $8.3 \pm 0.7^{a}$ & $10.0 \pm 2.1^{a}$ & $11.0 \pm 1.0^{\mathrm{a}}$ & $21.2 \pm 1.2$ \\
\hline LSD $5 \%$ & $0.66^{* *}$ & $1.50^{\mathrm{ns}}$ & $2.16^{\mathrm{ns}}$ & $2.23^{n s}$ & $1.22^{\mathrm{ns}}$ & $2.72^{\mathrm{ns}}$ & $2.06^{\mathrm{ns}}$ & \\
\hline
\end{tabular}

Values with same letter in superscript in row do not differ significantly

NS non-significant

***, ${ }^{* *}$ and ${ }^{*}$ significant at $0.001,0.01$ and 0.05 levels respectively

was found in the case of n-hexane extract of roots $(3.8 \mathrm{~mm})$. Ethyl acetate, $\mathrm{n}$-butanol, dichloromethane and water extracts of different parts was remained limited to $10 \mathrm{~mm}$ zone of inhibition while ethyl acetate and dichloromethane extracts of pulp showed zone of inhibition up to $12 \mathrm{~mm}$. The low bacterial growth inhibition might be due the absence of structural interaction between solvent, extracted compounds and bacterial strains. This has been evidenced in literature that the compounds of same class behave differently with bacterial strains such as quinolone based antibiotics encounter bacteria action with different efficacy and also face different mode of resistance from bacterial strains as well. Similarly different phenolic compounds and other biological active compounds extracted from natural sources also behave differently in different biological systems. Different 
solvents don't extract similar kind of natural compounds with same concentration and consequently don't show biological activities with same potential. Ethanolic extracts followed by methanolic extracts only presented the best antibacterial activity against both gram positive and gram negative tested bacterial strains due to its great ability to extract those polyphenolic and biological active compounds from natural sources which effectively act against broad spectrum bacteria. The weak antibacterial potential of water extracts is in good agreement with literature reports that hydrophobicity often act as domain driver of antibacterial activities [30,31].

Antibacterial study was performed using ciprofloxacin as a control antibacterial agent. It appears slightly more efficient to stop bacterial growth as compared to the highly active ethanolic pulp extract.

\section{Methods}

\section{Plant materials}

Generally different parts of the plants exhibit chemical composition varying from each other according to the cultivar conditions [32]. C. papaya fruit, leaves, bark and roots were collected from selected harvested areas of the lower Punjab province of Pakistan and used throughout this study. All parts of C. papaya were washed gently with tape water and then by using distilled water followed by drying (under shade) and grinding. The freeze drying method was also used to dry peel and pulp.

\section{Trace element analysis}

For the preparation of samples to analyze mineral composition, wet digestion procedure was used. Briefly, to $1 \mathrm{~g}$ of sample in a beaker added $5 \mathrm{~mL}$ of conc. $\mathrm{HNO}_{3}$. The solution was boiled till the volume was reduced to $1 \mathrm{~mL}$. Then $2 \mathrm{~mL}$ Hydrogen Peroxide $\left(\mathrm{H}_{2} \mathrm{O}_{2}\right)$ was added drop wise till the solution become clear followed by the dilution with $25 \mathrm{~mL}$ of deionized water. Trace and heavy elements in the samples of leaf, peel and pulp were analyzed by the use of Atomic Absorption Spectrophotometer (Hitachi Polarized Zeeman AAS, Z-8200, Japan) following the conditions described in AOAC (1990). Biological active metals included Cobalt $(\mathrm{Co})$, Copper $(\mathrm{Cu})$, Lead $(\mathrm{Pb})$, Iron $(\mathrm{Fe})$ and Zinc $(\mathrm{Zn})$ were selected to measure.

\section{Preparation of extracts}

Dried and stored powdered sample was extracted with each of the following solvents; methanol, ethanol, ethyl acetate, dichloromethane, $\mathrm{n}$-butanol and $\mathrm{n}$-hexane, in a 1:10 (w/v) ratio of C. papaya part to solvent, for 2 weeks with periodic shaking at regular intervals. After the extraction, the contents were filtered through Whatman \# 1 filter paper, followed by centrifugation at $13000 \mathrm{~g}$ for
$5 \mathrm{~min}$. Then all the filtrates were evaporated at room temperature or with rotary evaporator in case of more polar solvent system. The dry extract was then used to calculate the percent yield and further analysis.

\section{Determination of total phenolic contents}

Total phenolics in selected part of C. papaya were determined using the Folin-Ciocalteau reagent method [33]. Briefly, to the $50 \mathrm{mg}$ extract added $0.5 \mathrm{~mL}$ FolinCiocalteu reagent which was then diluted with $7.5 \mathrm{~mL}$ deionized water. The solution was then shaked well and kept it at room temperature for $10 \mathrm{~min}$ followed by the addition of $1.5 \mathrm{~mL}$ sodium carbonate $\left(\mathrm{Na}_{2} \mathrm{CO}_{3}\right)$ solution $(20 \%)$ and heated at $40{ }^{\circ} \mathrm{C}$ for $20 \mathrm{~min}$ in water bath. The heated solution was then cooled in ice bath and took absorbance at $755 \mathrm{~nm}$. The results were then compared with calibrated gallic acid curve and finally results were represented as mg gallic acid equivalent (GAE) per g dry matter.

\section{Determination of total flavonoid contents}

Total flavonoids were analyzed by commonly adopted procedure described by Dewanto et al. [34]. Briefly, to $1 \mathrm{~mL}$ of the test solution $(0.1 \mathrm{~g} / \mathrm{mL})$ added $5 \mathrm{~mL}$ distilled water followed by following steps; addition of $0.3 \mathrm{~mL}$ of $5 \%$ Sodium Nitrite, incubation for $5 \mathrm{~min}$, addition of $0.6 \mathrm{~mL}$ of $10 \% \mathrm{AlCl}_{3}$, and addition of $2 \mathrm{~mL}$ Sodium Hydroxide $(1 \mathrm{M})$ after another $5 \mathrm{~min}$ incubation period. The whole mixture was then diluted to $10 \mathrm{~mL}$ by adding distilled water. The mixture was then well shaked and took absorbance at $510 \mathrm{~nm}$. Total flavonoids were calculated in mg CE per g dry matter.

\section{Determination of antioxidant activity}

Antioxidant activity of different extracts of various parts of papaya was assessed by three different assays namely reducing power, inhibition of linoleic acid peroxidation assay and DPPH free radical scavenging activity.

\section{Determination of reducing power}

The reducing power of various parts of C. papaya was determined using procedure described by Yen \& Duh with slight modification [35]. Different extracts of 2-10 mg was added to $5 \mathrm{~mL}$ of sodium phosphate buffer ( $\mathrm{pH}$ 6.6) followed by the addition of $5 \mathrm{~mL}$ potassium ferricyanide $(1 \%)$ and the mixture was heated at $50{ }^{\circ} \mathrm{C}$ for $20 \mathrm{~min}$. After heating step, $5 \mathrm{~mL}$ trichloroacetic acid (10\%) was added and centrifuged the mixture at $1000 \mathrm{rpm}$ for $10 \mathrm{~min}$ at $4{ }^{\circ} \mathrm{C}$. To the first layer of centrifuged mixture added $5 \mathrm{~mL}$ distilled water and $1 \mathrm{~mL}$ ferric chloride solution ( $0.1 \%)$. Absorbance of the solution was determined at $700 \mathrm{~nm}$. All the samples were analyzed thrice and the average of the results was taken. 


\section{Determination of DPPH free radical scavenging potential}

DPPH free radical scavenging activity of different extracts of $C$. papaya was determined by following the method described by Iqbal et al. [36]. According to the procedure, to $1 \mathrm{~mL}$ of ethanolic extract solution $(25 \mu \mathrm{g} / \mathrm{mL})$, added $5 \mathrm{~mL}$ methanolic solution of 2,2'-diphenyl-1-picrylhydrazyl (DPPH) solution of $0.025 \mathrm{~g} / \mathrm{L}$ concentration. The contents were vortexed for $1 \mathrm{~min}$ and left to stand at room temperature for $20 \mathrm{~min}$ followed by measuring the absorbance at $510 \mathrm{~nm}$. Free radical scavenging activity was calculated using the following formula.

$$
\begin{aligned}
& \text { DPPH Inhibition }(\%)=\left[1-A_{1} / \mathrm{A}_{0}\right] \\
& \quad \times 100\left(\mathrm{~A}_{1}=\right.\text { Absorbance of sample, } \\
& \left.\mathrm{A}_{0}=\text { Absorbance of control }\right)
\end{aligned}
$$

The assay was replicated thrice for each sample and result was taken as mean \pm standard deviation.

\section{$\%$ Inhibition of linoleic acid peroxidation}

Antioxidant activity of all extract was determined using linoleic acid model system reported previously [37]. Briefly, in different extracts of C. papaya containing $5 \mathrm{mg}$ of dry extract added $0.13 \mathrm{~mL}$ of linoleic acid, $10 \mathrm{~mL}$ of pure ethanol, $10 \mathrm{~mL}$ Sodium phosphate buffer $(0.2 \mathrm{M}$, $\mathrm{pH} 7$ ). The total volume of the mixture was made up to $25 \mathrm{~mL}$ with distilled water and the mixture was incubated for $172 \mathrm{~h}$ at $37{ }^{\circ} \mathrm{C}$. At the end of $172 \mathrm{~h}$ the linoleic acid peroxidation inhibition was determined by thiocyanate method. Briefly, to $10 \mathrm{~mL}$ of $75 \%$ ethanol added $0.2 \mathrm{~mL}$ of sample solution, $0.2 \mathrm{~mL}$ of ferrous chloride solution $\left(\mathrm{FeCl}_{2}\right)(20 \mathrm{mM}$ in $3.5 \% \mathrm{HCl})$ and mixed sequentially. The solution was then stirred for $3 \mathrm{~min}$ and absorbance was noted at $500 \mathrm{~nm}$. A solution with linoleic acid but without sample was taken as negative control and solution containing synthetic standard antioxidant, BHT was taken as positive control.

\section{Antibacterial activity}

Antibacterial activity of different $C$. papaya extracts were measured using disc diffusion method as described earlier with slight modification [38]. Antibacterial activity was assessed against four bacterial strains $S$. aureus, $E$. coli, B. cereus, and P. multocida. Twenty milliliter media containing bacterial strain was poured into nutrient agar petri plats and allowed to set. After that, sterile filter paper discs $(10 \mathrm{~mm})$ placed on surface of the medium followed by loading $100 \mu \mathrm{L}$ sample $(10 \mathrm{mg} / \mathrm{ml})$ dissolved in DMSO onto filter discs. The solution of same concentration of ciprofloxacin was also loaded as positive control. Petri plates were then incubated for $18-24 \mathrm{~h}$ at $37^{\circ} \mathrm{C}$ in an incubator. At the end of incubation period zone of inhibitions was measured by zone reader.

\section{Statistical analysis}

The experiment were designed in a completely randomized design (CRD) with three replicates and data so generated for different attributes was analysed using a software named CoSTAT V 6.3 (developed by, Cohort software, Berkeley, California, USA).

\section{Conclusion}

This study was conducted to test the medicinal profile of all parts of $C$. papaya by extracting secondary metabolites with organic and aqueous solvents. Secondary metabolites are associated with numerous biological processes in living body, for example; defense system, biotic and abiotic stress. Total 42 extracts of different parts of C. papaya were examined using key in vitro biological assay models. Methanol and ethanol extracts of roots and bark showed good antioxidant activities in addition to leaves, peel and pulp extracts; however, methanol and ethanol extract of pulp and leaves showed promising antibacterial activities in addition to antioxidant potential. Ethanol and methanol both were found to be the best solvents of choice to extract natural products to get maximum medicinal benefits. The results obtained from this study could be more beneficient if individual or combined extraction of pulp, leaves, bark or peels is carried out with ethanol for preparing ready to use extracts to combat oxidative stress and bacterial infections.

\section{Abbreviations \\ C. Papaya: Carica papaya; S. aureus: Staphylococcus aureus; E. coli: Escherichia coli; B. cereus: Bacillus cereus; P. multocida: Pasteurellamultocida; TPC: total Phenolic Contents; TFC: total Flavonoid Contents; DPPH: 2,2-diphenyl-1-picryl- hydrazyl; ROS: reactive oxygen species; RNS: reactive nitrogen species. \\ Author details \\ ${ }^{1}$ Department of Chemistry, Government College University, Faisalabad 38000, Pakistan. ${ }^{2}$ Institute of Chemistry, University of the Punjab, Lahore 54000, Pakistan. ${ }^{3}$ Department of Chemistry, COMSATS Institute of Information Tech- nology, Abbottabad 22060, Pakistan. ${ }^{4}$ Department of Chemistry, University of Sargodha, Sargodha 40100, Pakistan. ${ }^{5}$ The Patent Office, Karachi, Pakistan. ${ }^{6}$ Department of Crop Science, Faculty of Agriculture, UPM, 43400 Serdang, Selangor, Malaysia.}

\section{Acknowledgments}

We dedicate this piece of work to very kind and beloved colleague and teacher Prof. Dr. Saeed Ahmad Nagra, who is no more longer accompanied us.

Received: 4 June 2015 Accepted: 11 January 2016

Published online: 03 February 2016

\section{References}

1. Dominique B, Sylvie L, Simon LD, Jessica J, Edith B, Martine C et al (2009) Antiproliferative and antioxidant activities of common vegetables vegetables; a comparative study. Food Chem 112:374-380

2. Miyake Y, Fukushima W, Tanaka K, Sasaki S, Kiyohara C, Tsuboi Y et al (2011) Dietary intake of antioxidant vitamins and risk of Parkinson's disease: a case-control study in Japan. Eur J Neurol 18:106-113 
3. Zeynep S. Agim and Jason R (2015) Cannon "dietary factors in the etiology of parkinson's disease". Bio Med Res. Article ID 672838, 16 pages. doi:10.1155/2015/672838

4. SchwabU Lauritzen L, Tholstrup T, Haldorsson TI, Riserus U, Uusitupa M, Becker W (2014) Effect of the amount and type of dietary fat on cardiometabolic risk factors and risk of developing type 2 diabetes, cardiovascular diseases, and cancer: a systematic review. Food Nut Res 58:25145-25170

5. Uttara B, Singh AV, Zamboni P, Mahajan R (2009) Oxidative stress and neurodegenerative diseases: a review of upstream and downstream antioxidant therapeutic options. Curr Neuropharmacol 7:65-74

6. Boskou D (2006) Sources of natural phenolic antioxidants. Trends Food Sci Technol 17:505-512

7. Yan Z, Baolu Z (2013) Oxidative stress and the pathogenesis of alzheimer's disease. Oxid Med Cell Longev 10:1942-2900

8. Madeo J, Elsayad C (2013) The Role of oxidative stress in alzheimer's disease. J Alzheimers Dis Parkinsonism 3:116-120

9. Tsang AH, Chung KK (2009) Oxidative and nitrosative stress in Parkinson's disease. Biochim Biophys Acta 7:643-650

10. Maria MB, Almeida Paulo HMS, Ângela MCA, Giovana MP, Carlos Emanuel CM, Geraldo AM et al (2011) Bioactive compounds and antioxidant activity of fresh exotic fruits from northeastern Brazil. Food Res In 44:2155-2159

11. Marisa MW (2006) Ascorbic acid, vitamin A, and mineral composition of banana (Musa sp.) and papaya (Carica papaya) cultivars grown in Hawaii. J Food Compost Anal 19:19434-19445

12. Otsuki N, Dang NH, Kumagai E, Kondo A, Iwata S, Morimoto C (2010) Aqueous extract of Carica papaya leaves exhibits anti-tumor activity and immunomodulatory effects. J Ethnopharmacol 127:760-767

13. Nguyen Thao TTS, Paul NP, Marie O, Hewa V, Amitha K (2013) Anticancer activity of Carica papaya. Mol Nutr Food Res J 57:1613-4133

14. Metrouh-Amir H, Duarte CMM, Maiza F (2015) Solvent effect on total phenolic contents, antioxidant, and antibacterial activities of Matricaria pubescens. Ind Crop Prod 67:249-256

15. Hauppauge Nabrzyski M (2013) Functional role of some minerals in foods. Miner Compon Food 5:363-388

16. Grembecka M, Szefer P (2013) Comparative assessment of essential and heavy metals in fruits from different geographical origins. Environ Monit Assess 185:9139-9160

17. Zakia K, Kong HS, NurHazerra BMZ, Chua HC, Irshad UHB (2015) Determination of polyphenolic content, HPLC analyses and DNA cleavage activity of Malaysian Averrhoacarambola L. fruit extracts. J King Saud Univ Sci. doi:10.1016/j.jksus.2015.01.004

18. Chirinos R, Rogez H, Campos D, Pedreschi R, Larondelle Y (2007) Optimization of extraction conditions of antioxidant phenolic compounds from mashua (Tropaeolum tuberosum Ruiz and Pavon) tubers. Sep Purif Technol 55:217-225

19. Turkmen N, Sar F, Veliôglu YS (2006) Effects of extraction solvents on concentration and antioxidant activity of black and black mate tea polyphenols determined by ferrous tartrate and Folin-Ciocalteu methods. Food Chem 99:835-841

20. Witayapan N, Songwut YW, Siriporn O (2010) Factors influencing antioxidant activities and total phenolic content of guava leaf extract. LWT-Food Sci Technol 43:1095-1103

21. Quan V, Sathira H, Paul DR, Michael CB, Phoebe AP, Christopher JS (2013) Effect of extraction conditions on total phenolic compounds and antioxidant activities of Carica papaya leaf aqueous extracts. J Herb Med 3:104-111

22. Lee SC, Norliza AL, SzeYL ChewTL, Mohamad RS, Ramlan AA (2011) Flavonoids and phenolic acids from Labisiapumila (Kacip Fatimah). Food Chem 3:1186-1192
23. Ock KC, Sang JC, Won OS (2007) Estimated dietary flavonoid intake and major food sources of US. Adults J Nutr 137:1244-1252

24. Shashank K, Abhay K.P (2013) Chemistry and biological activities of flavonoids, an overview. Sci World J Article ID 162750, 16 pages .http://dx.doi. org/10.1155/2013/162750

25. James MH, Zobert FD, Zary RB, Joanne MH, David BH, Seema B et al (2006) Flavonoid Content of US Fruits, Vegetables, and Nuts. Food Chem 54:9966-9977

26. Joana SB, Érica OB, Beatriz CS, Paula FM, Vitor CA, Jesuí WV (2014) Evaluation of solvent effect on the extraction of phenolic compounds and antioxidant capacities from the berries application of principal component analysis. Chem Cent J 8:48-56

27. Amarowicz R, Pegg RB, Rahimi PM, Barl B, Weil JA (2004) Free-radical scavenging capacity and antioxidant activity of selected plant species from the Canadian prairies. Food Chem 5:551-562

28. Isabel CFR, Ferreira Paula B, Miguel VB, Lillian B (2007) Free-radical scavenging capacity and reducing power of wild edible mushrooms from northeast Portugal individual cap and stipe activity. Food Chem 4:1511-1516

29. Rahmat AK (2012) Evaluation of flavonoids and diverse antioxidant activities of Sonchusarvensis. Chem Cent J 6:126-132

30. Dean GB, Tricia LMD, Moriah MG, Ruben T (2014) Trends and exceptions of physical properties on antibacterial activity for gram-positive and gram-negative pathogens. J Med Chem 57:10144-10161

31. lyer R, Ferrari A, Rijnbrand R, Erwin AL (2015) A fluorescent microplate assay quantifies bacterial efflux and demonstrates two distinct compound binding sites in AcrB. Antimicrob Agents Chem 59:2388-2397

32. Witayapan Nantitanon, Songwut YW, Siriporn O (2010) Factors influencing antioxidant activities and total phenolic content of guava leaf extract. Food Sci Technol 43:1095-1103

33. Sultana B, Anwar F, Ashraf M, Saari N (2012) Effect of drying techniques on the total phenolic contents and antioxidant activity of selected fruits. J Med Plants Res 6:161-167

34. Dewanto v, Wu x, Adom KK, Liu RH (2002) Thermal processing enhances the nutritional value of tomatoes by increasing total antioxidant activity. J Agric Food Chem 50:3010-3014

35. Yen GC, Duh PD (1994) Scavenging effect of methanolic extracts of peanut hulls on free radical and active oxygen species. J Agric Food Chem 42:629-632

36. lqbal S, Bhanger MI, Anwer F (2005) Antioxidant properties and components of some commercially available varieties of rice bran in Pakistan. Food Chem 93:265-272

37. Naqvi SAR, Mahmood N, Naz S, Hussain Z, Sherazi TA, Khan ZA et al (2013) Antioxidant and antibacterial evaluation of honey bee hive extracts using in vitro models. Mediterr J Nutr Metab 6:247-253

38. Sahar A, Naqvi SAR, Hussain Z, Nosheen S, Khan ZA, Ahmad M et al (2013) Screening of phytoconstituents, investigation of antioxidant and antibacterial activity of methanolic and aqueous extracts of Cucumissativus. J Chem Soc Pak 35:456-462

\section{Submit your manuscript to a SpringerOpen ${ }^{\circ}$ journal and benefit from:}

- Convenient online submission

- Rigorous peer review

- Immediate publication on acceptance

- Open access: articles freely available online

- High visibility within the field

- Retaining the copyright to your article

Submit your next manuscript at $>$ springeropen.com 